\title{
Thomas Bird Mosher and the Literature of Rapture: A Chapter in the History of American Publishing
}

\author{
William E. Fredeman
}

It is a curious irony of the Arts and Crafts Movement, which in England dates roughly from the building of Red House and the founding of the Firm of Morris, Marshall, Faulkner \& Co. in the r86os, that its latest endeavour, printing, should be its most lasting legacy. Morris \& Co. had been in operation for over thirty years, engaged in the manufacture of furniture, carpets, tapestries, wallpapers, stained glass, and other artefacts, when Morris launched his Kelmscott Press. Its first title, The Story of the Glittering Plain, issued in April I89I, followed two experiments, under the Chiswick Press imprint, and represented, for Morris, the culmination of a long interest in publishing. Virtually at the inception of The Earthly Paradise in I 865, he had planned with Burne-Jones an illustrated edition of that work, the history of which is meticulously traced by Joseph Dunlap in The Book That Never Was (r97I). That it never was, delayed, perhaps by two decades, the private press movement that burgeoned on both sides of the Atlantic in the last decade of the nineteenth century.

Apologists for William Morris argue strongly for the primacy of his influence, but while Morris \& Co. had established a showroom in New York as early as $\mathrm{I} 88 \mathrm{I}$, it was only one of several organs promoting the arts and crafts. In 1884 , A.H. Mackmurdo and Selwyn Image founded the Century Guild and issued an abortive single number of the journal the Hobby Horse, which was revived two years later. In the same year, W.R. Lethaby and Walter Crane started the Art Workers' Guild, and in I 888, C.R. Ashbee founded the Guild of Handiwork. Whereas Morris appears to have come to printing, as it were, by the backdoor, extending his overall concern with design to books, some of his contemporaries fostered quite independently the idea of fine printing as an end in itself, removed from those broader social reforms that inspired Morris's multifarious activities. In the Hobby

This paper was given at the $42 \mathrm{~d}$ Annual Meeting of the Bibliographical Society of Canada held at the University of British Columbia, Vancouver, British Columbia, on ro June 1987. 
Horse, Image and Mackmurdo, who is generally credited with designing the first Art Nouveau book cover - for Wrenn's City Churches (1883)-produced a journal that was unique among magazines of the day; and Ashbee went on in 1898 to start the Essex House Press, the last of whose publications in I909 was The Private Press: A Study in Idealism.

The history of private presses is a long one, involving a number of amateurish, sometimes vanity, enterprises, but including, in the century before Kelmscott, to name only a few highlights, several presses that took their names from the estates of their founders, a tradition that still persists. Horace Walpole's Strawberry Hill Press (I757-1789), Sir Egerton Brydges's Lee Priory Press (I813-1823), Sir Alexander Boswell's Auchinleck Press, and the Hon. Ivor Bertie Guest's Canford Manor Press (1 867) were all conducted by men of rank and material substance. In contrast, presses such as those established by Charles Daniel (I845-I906) and Gaetano Polidori (I840-I850) were namesake presses, less grandly endowed. During the same period, almost the only significant American private press was the Appledore Press (? I 867-I 895) set up by the expatriate English engraver William James Linton in Hampton, Connecticut, whose output was restricted almost exclusively to limited editions of his own volumes.

Après Kelmscott (I89I-1898) le déluge: in quick succession, a host of English and American private presses was founded, many of them less in direct imitation of Morris's printing than simply manifestations of the new emphasis on book design promulgated by Morris and others associated with the revival of fine printing, the impact of Art Nouveau on book design, particularly illustrations, and the tenets of the Aesthetic Movement, which focussed on all aspects of the life beautiful, free from the social theorizing that buttressed the Arts and Crafts Movement. These influences, as Susan Otis Thompson convincingly argues (I977), generated two related, sometimes overlapping, but essentially distinct typographic styles, the classic and the romantic, which subsume, taxonomically, works influenced by either neo-classical or Aesthetic models, on the one hand; on the other, those imitating the productions of William Morris and the Arts and Crafts Movement. In America, these styles were epitomized by the extremes of the two most popular publishers of the fin de siecle, Thomas Bird Mosher of Portland, Maine, and Elbert Hubbard at the Roycroft Press in East Aurora, New York, who began publishing in I89I and I 896 respectively.

While these two presses were essentially commercial, Mosher and Hubbard were both concerned with the book as artefact, and both issued books in limited editions. Neither publisher achieved the reputation of the greatest of the private presses in Great Britain - St. John Hornby's Ashendene Press (I 894), Lucien Pissaro's Eragny Press (1 894), Charles Rickett's 
Vale Press (I896), James Guthries's Pear Tree Press (I899), T. CobdenSanderson's Doves Press (I900), or Elizabeth Yeats's Cuala Press (I902); but some of Mosher's best work compares favourably with the productions of the more distinguished American private presses of men like Daniel Berkeley Updike at the Merrymount Press (1893), Clarke Conwell at the Elston Press (I90I), and Frederick and Bertie Goudy at the Village Press (I903). However, because Mosher was a publisher and not a printer, no convincing case can be made for his influence on these craftsmen. Bruce Rogers and Will Ransom, two of the most important American book designers, whose earliest work dates from this period, praised Mosher's work. Although he was critical of Mosher's type sizes and his too 'dainty bindings,' Ransom nevertheless praised his work over Hubbard's on the grounds that Mosher's twin concerns with fine writing and fine printing, involving a typography that was at once 'sane and charming,' made the writings of 'some of the most delightful stylists among modern authors' available to Americans for the first time. And Bruce Rogers, whose first book designs were commissioned by Mosher for his I 895 edition of George Russell's Homeward Songs by the Way, and who, fifteen years later, inscribed a copy of his IV Sonnets / Wordsworth (I909) to Mosher, as 'the Aldus of the XIxth Century / from an amateur printer' (Strouse I964, p. 62), is reported by A. Edward Newton as having told a member of the Grolier Club, 'I would rather have done his work than mine' (p. I24).

William Morris, Emory Walker, and Charles Ricketts are 'authoritatively bracketed,' as Ransom says in his Private Presses and Their Books, as 'the masters of the revival of great printing.' Of that triumvirate, Morris is traditionally regarded as the founding father, and Susan Thompson's American Book Design and William Morris is only the most recent and most extensive examination of Morris's influence on American printing and publishing. Printing historians tend to lump Mosher and Hubbard together as disciples of Morris, and Thompson concludes her parallel discussions of the two American publishers, in unequal chapters on Mosher as 'Aesthetic Pirate' and on Hubbard as 'An American William Morris,' with the interesting, if somewhat anomalous, observation, that

good taste becomes perhaps less necessary with the distance of time, so that Hubbard's extravagance now looks charming and Mosher's restraint a trifle chilly. The clean, pure silhouettes of the latter's books are, nevertheless, an antidote to all those limp suede bindings of Hubbard's. (p. I07)

It is not pertinent to the theme of this paper to debate either the lasting significance of William Morris or the relative importance and quality of Mosher and Hubbard. It should be noted, however, that, without in any 
sense denigrating Morris's contribution to the revolution in printing, not all critics toe a common line in assessing his influence. Holbrook Jackson, for example, in a Morris Centenary dinner address to the Double Crown Club in I934 on 'The Typography of William Morris,' later collected in The Printing of Books (1938), argued that it was the 'magnificence of the Kelmscott adventure' that 'impressed and influenced printers' (p. I 82) rather than the architectonics - 'the organic assembly of paper, type, and binding' - or the pursuit of beauty: 'Bad taste in the arts,' Jackson insists, 'is invariably the result of beauty-mongering.' Nor was Jackson willing to concede any originality to Kelmscott books; Morris, he says, was essentially 'a revivalist, and all his work is derivative' (p. I76). Kelmscott books, Jackson concludes, reflecting, as they do, Morris's intense typophilia and his preoccupation with decoration, are 'overdressed,' and 'ask you to look at them rather than to read them.' And because 'reading is best when you are least conscious of print or paper or binding,' Kelmscotts are for him 'typographical curiosities' (p. I75) - 'models of what a book should not be' (p. I85, my emphasis). Jackson's view is admittedly an extreme one designed to enflame modern-day Morriseans, but it does provide a convenient instrument for discriminating between Hubbard and Mosher.

In his Roycroft manufactures, Fra Elburtus, as he was quaintly known to the Roycrofters, servilely imitated, even parodied, Morris, giving rise to Jackson's observation quoted in Roderick Cave, The Private Press (I97 I, p. I 55l, that the Kelmscott Press 'found its nemesis in Elbert Hubbard's Roycroft books.' Less flamboyant than Hubbard, Mosher responded to the subtler influences that Morris unquestionably exerted on the revival of printing. If readability is the ultimate desideratum in the making of books, Mosher succeeded, as A. Edward Newton notes, where Morris, and even more patently his American shoehorn, Hubbard, failed. Notwithstanding Morris's avowed Aims in Founding the Kelmscott Press, to produce books that 'would have a definite claim to beauty' and that would be 'easy to read' without dazzling the eye or intellect of readers 'by eccentricity of form in the letters,' Kelmscott books are not, by any objective standard, readable, though they are beautiful. Hubbard's imitations, in the words of Roderick Cave, are merely 'horrid': 'articrafty in the most vulgar and meretricious sense - poorly printed on rough paper, using ugly types with the nastiest of art nouveau decoration, and bound in the cheap soft suede known appropriately in the trade as "limp ooze" (p. I 55). In contrast, Mosher - who, paradoxically, receives only two casual references in Cave's monumental study - produced books that are, in their very simplicity, eminently readable. Mosher's reputation does not rest solely on his artefacts. His books are elegant edifices, appropriate to the authors who inhabit them; but Mosher's claim on a prominent place in the history of 
American publishing depends equally on a two-pronged philosophy that, first, extended the idea of the total book to include its contents as well as the externals of paper, type, and binding, thereby achieving an organic unity; and, second, sought practical means of printing, marketing, and disseminating inexpensive and tastefully chosen texts to a select audience whom he consciously hoped to educate. This was Mosher's goal, and in working toward it he discovered a middle ground between the exclusivity of Morris's Kelmscott Press books, the prices of which, because Morris eschewed machine technology in everything he produced, precluded their acquisition by the populace he sought to serve, and the tasteless, exploitative hucksterism of Elbert Hubbard.

In October I89I, when Thomas Bird Mosher published his reprint of George Meredith's Modern Love, a poem whose appeal for him must have lain in the narrative parallels to his own unhappy first marriage, he was nearly forty years of age, and there was seemingly little in his background to prepare him for the new career on which he was embarking. He may well have been, as Christopher Morley wrote, 'the potential author of one of the most fascinating autobiographies that were never written' (I926, p. I I 2), but the disk files on which that story was recorded have long been lost, and it would require a powerful retrieval program to resurrect them. The few facts that have been pieced together by Keith Gibson Huntress in his 1942 dissertation on Mosher, by Norman Strouse in The Passionate Pirate (1964) and by Ray Nash in his prefatory biographical essay to Benton L. Hatch's Check List (I 966) derive mainly from Mosher's own writings his prefaces to the Bibelot, his introductions to his printed books, and those charming but, in the main, personally unrevealing essays printed in his annual catalogues and collected in the two Amphora volumes of I9I 2 and 1926; from a handful of impressionistic recollections of friends, such as Morley and Frederick A. Pottle; from interviews with his long-time personal secretary, Flora M. Lamb, who survived him, carried on the Mosher Press after his death, and oversaw its sale and transfer to the Williams Book Store of Boston at the end of I94I; from occasional correspondence and business papers that survive in the Mosher archive at Harvard; and from a few fugitive published accounts. The record has it that at the time of his death he was virtually unknown in his home town of Portland.

What is known is that he was the son of a sea captain and ship owner; that he was born in Biddeford, Maine on I I September I852; that he abandoned formal education after completing grammar school in Boston, went to sea with his father for three years immediately thereafter, returned to Portland in the summer of $\mathrm{I} 870$, and took a job as clerk in a local firm dealing in law reports, stationery, and textbooks; that he secretly married a girl 
named Ellie Dresser a few months after his eighteenth birthday, and remarried her the following year; that he met a young man with whom he shared a literary vacation in Springfield, Massachusetts in the summer of I875; and that he worked briefly in the years between I870 and I882 at various jobs in New York, Philadelphia, and Boston, and, probably after Ellie deserted him in I879, clerked for a time in a bookstore in St. Louis. In December I 882, shortly after his divorce from Ellie, Mosher, with funds supplied by his father, entered into a junior partnership, with his former employer, Ruel T. McLellan, in the firm of McLellan, Mosher and Co. where he gained practical experience in publishing textbooks, such as George J. Varney's A Brief History of Maine, to which he contributed a preface. He lost his father in I885, and went into bankruptcy in I890. At mid-life, he turned publisher, concentrating on belles lettres and books in limited editions; remarried in I892, and had two sons by 1907; was elected to the Grolier Club in 1895 , and in that year started a magazine, the Bibelot, which went through twenty volumes; he travelled to England in I90 I; was awarded an Honorary M.A. by Bowdoin College in 1906; suffered a stroke three years later, and died on 3 I August I923.

But what of Mosher the man, about whom this skeletal survey reveals next to nothing? He is reported to have hidden a gentle disposition beneath a gruff exterior. His anonymity in Portland suggests a private man, but from printed reminiscences he comes through as portly and genial, and, in the right company, garrulous. In appearance, he bore a close resemblance, as the Times Literary Supplement reviewer of Hatch's bibliography noted, to President Taft. Principally, though, he was bookish: an erudite, serious, and sensitive collector, who read his books and who was willing to discuss them with a few kindred spirits, some of whom, like Pottle in his reminiscent essay entitled 'Aldi Discipulus Americanus,' published a few months after Mosher's death, have left behind nostalgic accounts of happy encounters with Mosher in the comfort of his office-library on Exchange Street or in his home, both of which were dominated by book-lined walls. And he was a lover of literature, especially the writings of mid-to-late nineteenthcentury poets and belles-lettrists, his area of specialization as a publisher.

But even these details are mere gleanings; occasional glimpses offering some insights into the man, they do not present him in the round. Mosher's true biography, his 'buried life,' is not really documented by the factual record. It is, perhaps, best discoverable in his publications, which reflect both his taste and his mission, and in the two equally nebulous personalities, who, apart from his father, appear to have figured most prominently in his life, Jane Sonntag and Leopold Lobsitz, the first of whom exists, literally, in name only; the other died at the age of twenty-one: both were the dearest friends of Mosher's youth. 
Before pursuing these elusive shadows in his life, however, it is necessary to pose a question, already hinted at, which is crucial to any attempt to comprehend Mosher as man and publisher. How, where, and when did Mosher, given his background, acquire the detailed knowledge of literature and the taste and sensibility evident in his choice of the poets and writers he published? In an impressionistic essay entitled 'A Golden String,' first published in the Saturday Review of Literature more than sixty years ago, Christopher Morley put the question this way:

What was there in this hearty sea-bred uncolleged down-easter that made him open so many magic portholes? He had the pure genius of book-fancy; an uneducated man, as uneducated as Chaucer and Lamb and Conrad; and I like to think that when he took Aldus' device for himself there was some memory of the time when an anchor meant more to him than an emblem printed on a title-page. (Amphora 2, p. I Io)

And memory does, after all, provide a key. In one of his best essays, 'The Books I Shall Not Read Again' (a title lifted with slight modification from a line in Gissing's The Private Papers of Henry Ryecroft, which Mosher published in I9I4), reprinted in I9I 2 in that 'breviary for book-lovers' that he entitled Amphora, he recounts the story of his years at sea as an impressionable teenager, most of which were spent poring over the I 40 dramatic compositions, commencing with Comus, contained in the 34 volumes of Bell's British Theatre, which were bought for him by 'an indulgent father in the winter of $1866-67$ when I crossed the Atlantic to meet him in Hamburg and began a voyage which did not end until the late summer months of I $870^{\prime}$ (p. I73). These volumes, Mosher confides, which introduced him to a 'New World' of writing belonging to 'the Old World of the Eighteenth Century' - Bell's reprint of 'the most esteemed plays' was published in I792 - 'first unlocked to me the treasure-trove of English Literature' (p. I74). Besides the plays themselves, Mosher's imagination was arrested by the provenance of the set, each volume of which 'bore the delicately written signature of an unchronicled and shadowy Jane Sonntag' (p. 173). 'Now,' Mosher reminisced nearly half a century later,

how gladly would I know the history of my set of Old Plays. Who was Jane Sonntag, its original owner, and what chain of circumstances set these volumes to the second-hand shop at Hamburg? Possibly no other form of human art retains that first fine careless rapture - the magic of a forgotten day - still alive to work its will upon me as do these dear, dumpy eighteenmos. My regard for George Farquhar dates from this period: The Recruiting Officer, Sir Harry Wildair, The Inconstant, The Beaux' Strategem, - a world of passion- 
ate dust, once living, but now gone! The name itself - Jane Sonntag! In reading the tragedy of Gustavus Vasa I found an old-fashioned pin, hand wrought, with welded head, inserted as a placemark when the volume was laid aside for that day's reading, and if ever resumed this little relic would serve as a reminder. Truly, it may belong to a period, 'when these old plays were new.'

Echoing Wordsworth on Nature in 'Tintern Abbey,' Mosher concludes:

\begin{abstract}
No, I shall never again read books as I once read them in my early seafaring, when all the world was young, when the days were of tropic splendour, and the long evenings were passed with my books in a lonely cabin, dimly lighted by a primitive oil-lamp, while the ship was ploughing through the boundless ocean on its weary course around Cape Horn. These shadows of the past are still very real to me. But fellow-travellers over the same road may be reminded by my musings of familiar stations which they have passed likewise in their life's journey. (pp. 174-75)
\end{abstract}

This is a romantic, if not a sentimental, view of both life and art, but it is equally central to an understanding of the development of Mosher's literary taste, accounting for the appeal that particular classes of writing had for him, and of his philosophical ideals as a publisher, both of which were based, in part at least, on a theory of Palingenesis, compounded from a congeries of sources: the beliefs of the hermetic philosophers, the mystic books of the East, especially the Bhagavad-Gita, The Rubáiyát of Omar Khayyam, The Kasidah of Haji Abdu el-Yezdi, the writings of Ruskin, Pater, and Yeats, and the poetry of Whitman, Longfellow, and Tennyson, whose commitment to the principle of 'the Passion of the Past' inspires so many of his poems. In the evolution of these views, Jane Sonntag served as a kind of extended metaphor, a symbol, for the young and impressionable Mosher.

Although Leopold Lobsitz is a ghost from Mosher's actual rather than his imaginative life, little is known of him beyond the dates of his birth and death (I October I 858-i 7 February I 879), which Mosher records in the Amphora, to whose memory the book is dedicated. He is first mentioned simply as 'my friend to be, Leo,' in the foreword Mosher wrote for his I906 catalogue entitled 'In the Bright Lexicon of Youth' (a title adapted from Bulwer-Lytton's Richelieu), in which Mosher, reliving a 'summer's brief vacation' in Springfield, Massachusetts in I875, describes his encounter with 'a youthful High School graduate,' whose brief history is recounted in a footnote (p. I I 5). At the time of their meeting, Mosher was twenty-three; Leo was six years his junior, and Mosher, though well-versed in dramatic literature, may, under the influence of this precocious High School gradu- 
ate (which Mosher was not), have been introduced to poetry as a distinct literary genre. He recounts their reading together 'poets new and old,' mentioning specifically Browning's Paracelsus and The Ring and the Book and Whitman's Leaves of Grass, and dabbling in Buckle, Lecky, Spencer, Darwin, Huxley, and Mill. Their friendship, it seems - from Mosher's allusion to a 'little packet of Leo's letters' that he has been consulting - lasted beyond the period of personal contact, until Leo's untimely death less than four years later. Whether Mosher had an equal impact on Leo is not known, but from the younger man he gained what he calls 'a gleam of the Vision Splendid.' 'Is it not well to speak of these things?' Mosher asks.

This boy, with his love of the True, the Beautiful, the Good became my friend. Without him I would have suffered irreparable, life-long loss. This friendship still has its beneficial results in reacting upon the good work I hope to achieve. (p. II6)

It is clear from Mosher's account that Leo was for him the aesthetic equivalent of Hallam for Tennyson: a friend, a mentor, a source of future inspiration. Like Hallam, he was a younger man, who had died before he could deliver on his enormous talent and promise; and, Mosher, as Tennyson with Hallam, kept his memory ever green:

Thus ... I have come to see that the thing of Beauty in art, in letters, in music, - in a word the beauty of an idea, - is given to few to create, while to enjoy it, should be the inalienable birthright of all. Hence I accept Literature for what it seemed in those golden hours to my friend and myself, a guide with whom we could trust ourselves in the dark as with a lamp that the night of ages has never extinguished. What, think you, are all its messages and ministries, if not addressed to this eternal need in the soul of man? They cannot fail us.... How else evolve a deeper and undying music out of an otherwise dead and numb Past...? The revelation of just this truth came to me and my friend over thirty years ago. I wish to transmit it to others who pass along the self same way. (pp. II6-I7)

It is safe to assume that between 1875 and I 89 I Mosher continued a regimen of reading, broadening his horizons and entrenching his familiarity with the older and modern classics of English Literature. In the Eighties, when he had a readier and more reliable source of income, he began systematically to collect books, as the catalogue of his library compiled in I887-89 bears witness. In this decade also he obviously developed that keen business sense evident in his later management of the Press. At the same time as he was conducting his business, the idea of sometime 
becoming a producer, as well as a reader, of books was simmering on the back burner of his aspirations, as he slowly formulated his philosophy of publishing.

Emile Pons in his La Jeunesse de Jonathan Swift points out that Swift began his career with a set of controlling ideas that he never abandoned. So, too, Mosher from the start had firmly formulated views on what he hoped to achieve as a publisher. His introduction to literature had come by way of a thirty-four-volume anthology of the English drama, and he saw his mission as essentially that of an anthologist - a 'resurrectionist' his friend William Marion Reedy, Editor of the St. Louis Sunday Mirror, called him. Mosher would not have taken umbrage: his second 'List of Books' in I895 contains this epigram from Emerson:

We are as much informed of a writer's genius by what he selects as by what he originates. We read the quotation with his eyes, and find a new and fervent sense; as a passage from one of the poets, well recited, borrows new interest from the rendering. As the journals say, 'the italics are ours.'

Summarizing Mosher's achievement, Reedy continues:

The perfect marriage of thought or feeling with expression was what Mosher sought - and found, and gave to us. And to that union he added another element - beautiful, chastely beautiful printing. His idea ... has been to [set] and [lead] people in the way of culture - not the culture that has for object one's superiority over others, but the culture that is inclusive in its effect, the culture that is essentially sympathy with all the living. (pp. I89-90)

Reedy was referring specifically to the Bibelot, Mosher's little-magazine anthology that Reedy labelled 'an encyclopaedia of the literature of rapture,' but the editor's own statement of purpose in the first number of that journal in January I 895 is no less applicable to his other publications: 'To bring together the posies of other men bound by a thread of one's own choosing.' He put it more messianically in 'The Vision Splendid,' an essay in his I907 catalogue:

To what conclusion would I, therefore, bring you? To the sole viewpoint that I had in mind, the 'one thought ever at the fore' in the work I offer: that in it all and transfusing it all should be some of this limitless vision - the Vision Splendid which does not fade away! (Amphora, p. 67)

A similar message runs consistently throughout the forewords of his catalogues, which, quaintly composed in third person until he abandoned the 
practice with a flourish in I905, contain the fullest accounts of his philosophy of publishing.

As to the works he selected, Mosher followed his own taste, concentrating, as he said in the preface to the Bibelot on 'those exotics of Literature that might not immediately find a way to wider reading,' re-sowing them in 'fields their authors never knew.' 'It was not the publisher's wish,' he wrote in his second catalogue (I895), quoting from the same preface, to exploit the new

forces and ferment of fin de siècle writers. Rather he has sought to appeal to a more catholic and saving taste in Literature 'that is not of today or yesterday.' He would offer the less accessible 'things that perish never,' showing by his printed work that beautiful typography and inexpensiveness need not lie far apart.

His 'theory of book-making,' however, did not extend to providing his readers with a definitive group of books, as he said in his Foreword to his I903 catalogue; and in 'The Great Companions' (I909), he decried the ideas of both the 'Best Hundred Books' and the 'three or five foot shelf of books' as 'crass method[s] of laying hold upon the intellectual treasuretrove of the ages' (p. 96). Rather, he envisioned something more along the line of Edmund Gosse's concept of an 'ideal library' - 'a small one where the books are carefully selected and thoughtfully arranged in accordance with one central code of taste' - in this instance, Mosher's own. The I903 Foreword also provides the best synthesis of Mosher's ideals with his business practices, for it was the translation of all his lofty ideals and aims into practical terms that was to become the real test of Mosher's acumen and ultimately the measure of his success: 'What then does Mr. Mosher claim for his products as distinct and different,' he asks, after comparing his total output of 160 books produced over a dozen years with the annual production of a score of publishers:

For one thing, this: If Literature is, as some of us believe, finally resolvable into and coextensive with the term Ecstasy, and if the comprehension of Literature is not a mere process of formal logic but rather a return through the heart to the lost garden of the heart, then this collection most decidedly offers aesthetic values not elsewhere discoverable in like combination.

First and last, the production of these books has been a labour of love, beg[u]n as an escape from the commercialism which as one grows older tends to obscure and make less realisable the things that are more excellent. Not for mere profit in dollars and cents but from the desire of producing beautiful books at a moderate price - 'things of beauty rather than of mere utility' - 
thereby inducing that personal relationship between craftsman and client without which all doing is labour misapplied - was and is the measure of our intent in reaching out towards that ever-growing republic of booklovers, whose appreciation is alone worth while. (p. 6)

Abhorring cheap books and determined at the outset not to produce expensive ones, as Pottle noted, Mosher began with understandable apprehensions and predictions of instant failure. He told Anthony J. Philpott in an interview in the Boston Globe in I 897, 'I never dreamed, when I started on this venture six years ago, that it would be such a success.' Mosher's formula for that success involved seven specific strategies:

I. The adoption of the net price system, postage included, which, by virtually eliminating the middleman - only a handful of bookstores (Brentano's in New York, Paul Elder in San Francisco) carried his books in stock - reserved the bulk of the profits to the publisher and insured payment in advance.

2. The efficiency and cheapness of the post; prices included postage and books were shipped the same day an order was received. 'The mailing system is now so perfect throughout the Postal Union,' he informed his readers in I90I, 'that delivery is guaranteed to any part of the world by the publisher.'

3. The publication of printed catalogues in lieu of book notices and advertisements in newspapers and magazines. He did, of course, advertise, and even sent out a restricted number of review copies, but in general he depended on his lists and his network of customers to advertise his books. His views on these matters are discussed fully in his foreword to his I9OI catalogue.

4. The practice, honestly stated from the beginning, of reserving the right to increase prices when a first edition was nearly exhausted or when the work was not to be reissued, as was the case with several of his series. In the case of Bibelot, which in 1895 sold for a nickel, post included, he held back 500 copies for eventual binding-up to sell as sets when the journal was completed.

5. The institution of a reprint policy based on demand. Early on, his stated policy was to abjure reprints, and neither of his first two series, the English Reprint Series and the Bibelot Series, was ever reprinted. However, he appears to have come early to the recognition - if it was not, indeed, part of his original intent - that his policy of issuing editions that 'should not be so large as to almost necessarily result in depreciated remainders; nor yet so very limited as to render their value a fictitious one' (1895) had a distinct appeal to collectors. Over the course of his career, the reprint editions almost certainly supported the business. 
6. The operation of a non-labour-intensive business. Until I897, when he employed Flora Lamb as secretary, Mosher ran what was essentially a one-man operation, employing only one or two clerks and stock boys. Owning only his ornaments, Mosher relied on local, inexpensive printers. Most of his books were printed by Smith \& Sale, located above his office on Exchange Street, but he also used Brown, Thurston and George D. Loring, whose shop was across the hall.

7. The selection of modern titles that did not have copyright protection in America and therefore did not involve the payment of royalties, a practice that explains the paucity of American writers in his canon.

In combination, these factors enabled Mosher to keep his prices low and ensured his success, which, contrary to expectations, was almost immediate, although the momentum of the press and the accumulation of a backlog of original and reprint editions took several years to establish. By I908, he was able to repay the loan he had taken out against his father's estate, although with the death of his mother in $\mathrm{I} 907$, he probably received a reasonable inheritance (see Nash in Hatch, p. 23). His decision to forego royalties, however, gave rise in his own lifetime to charges of piracy and a series of press controversies that have tended to overshadow the more positive aspects of his life and work.

Mosher books, like the Gibson and 'Taylor-made' girls of the same era, have a quality that makes them instantly recognizable. In his first book, Meredith's Modern Love, Mosher established a standard 'look' from which he seldom departed. Viewed from the vantage of the advances made in book design in the last half-century, Mosher's productions admittedly now appear somewhat dated - 'fussy, fragile, and precious,' as Ray Nash says of them - but, as indicated in the first part of this paper, in the context of American book production at the beginning of the I890s, the books emanating from Portland, Maine were regarded as innovative departures in popular printing. Press response in New York, Boston, and Philadelphia was enthusiastic, and contemporary notices were punctuated with calorific hyperboles describing his productions. Adjectives like 'fastidious,' 'perfect,' 'artistic,' 'captivating,' 'elegant,' 'dainty,' and 'charming' abound in these early critiques. A writer in the Philadelphia Public Ledger of I9 December I894, observed that Mosher 'seems to have solved the problem how to present a choice poem in choice dress at a very small price.'

For all his books, Mosher designed a common dress, but the claim of some critics that they are simply monotonous replications is unjustified. His early decision to print titles in different series - he created fifteen separate series in all - insured a wide variety of formats and states. No two of 
the ninety-six titles in his largest series, for example, the Miscellaneous, a name he adopted only after he had printed several titles that did not belong to other on-going series, are look-alikes. The fifty titles in the Old World Series, however, because they were the most frequently reprinted and are now the most readily available, tend collectively to be boring, although, in mint condition, individual volumes are aesthetically satisfying.

What all the books share is an internal stylistic uniformity. With the exception of two facsimiles, all are printed from hand-set type, distributed after each edition. The least original aspect of Mosher's books is their type, almost invariably either old-style Roman or a modified Caslon; the Bibelot Series was set completely in italic type. His pages, however, are neatly composed and characterized by a clean, crisp quality. The books were printed on hand-made paper, usually Van Gelder, made expressly for Mosher in Holland, but he did print a few on Kelmscott, Italian, or other wove papers. For most titles in all series, a limited number of copies were available on Japan vellum - the Brocade Series, so named because of the decorated slipcases, was issued exclusively in Japan vellum - and forty-five separate titles were printed in a few copies - never more than ten - on pure Roman vellum. Since most volumes were bound either in Japan vellum or paper covers, each was protected by parchment wrappers and a slip case, on the spine of which the title was usually printed. Additional variety was provided in some series by boxing sets of related volumes, such as the Morris titles in the Brocade Series.

Most of Mosher's books were issued in limited editions, generally common to a series, with certifications identifying the number printed either on the verso of the title page or in a colophon. In size, these range from the two privately printed volumes issued in 3 and 5 copies only, the second of which is Mosher's own Arthur Symons: A Bibliographical Note (H722), to the I 500 copies of the twelfth edition of Burton's Kasidah (H682), which is the largest edition in the Old World Series and probably the largest edition he printed. Most series carried limitations of between 400 and 950 copies, but the twelve titles in the Reprints from the Bibelot Series, were issued only on Japan vellum in editions varying in size, depending on the title, from 25, to 35 , to 50 copies, making them the scarcest of all Mosher's productions. Although Hatch and Strouse both have reservations about the reliability of Mosher's certifications - and there is evidence of occasional confusion on the publisher's part - his statements on limitations are generally reliable, and there is no suspicion of conscious deception.

The publication of Benton L. Hatch's Check List in I 966 made available for the first time a complete listing of the Mosher publications, including all the reprints, the Bibelot volumes, and the catalogues, each of which is given a separate number. Each title is identified by series and number 
within the series, and a brief collation is provided for each volume. In an Appendix, based in part on a typescript prepared by Flora M. Lamb, Hatch lists fifty-nine privately printed titles, a few of which he was unable to locate. The volume contains a thorough author and title index which enables one to track a given title's course, but there is no breakdown by series. Hatch examined, wherever possible, actual copies in order to confirm his physical descriptions, but he provides little information regarding the contents of the volumes or their status, though he does note, for example, that the second edition of Wilde's Poems in the Miscellaneous Series (H248, p. 34I) contains new material. Only by examining each item is it possible to get an overview of a canon as large as Mosher's, and the statistical surveys provided as attachments to this paper are designed to convey some sense of the nature and scope of Mosher's total output.

Mosher's choice of authors, both in his published books and in the selections printed in the Bibelot, reflecting, as has already been noted, his personal taste, reveals an extraordinary catholicity, but as the Frequency Survey shows, his list is dominated by some sixteen writers from the period I 850 to the end of the century who account for nearly half the individual numbers of the Bibelot and just over half his original reprints. That last oxymoron is intentional, for one of Mosher's main distinctions as a publisher is that he made available in North America, often for the first time, editions by British writers published only in England. While many of his favourite writers - Arnold, Morris, Rossetti, and Swinburne - had been published in America for many years, his printings of other authors constitute their first American editions. Robert Bridges, Ernest Dowson, W.E. Henley, Richard Jeffries, Andrew Lang, Vernon Lee, Fiona MacLeod (William Sharp), George Meredith, Walter Pater, Arthur Symons, Francis Thompson, and James ('B.V.') Thomson all first appeared in America in Mosher editions, and all, in a strict, if not a legal, sense were piracies. Not all Mosher's editions were unauthorized, however; he often made arrangements with authors and publishers to reprint their works, as he did with Fiona MacLeod, whose identity Mosher became apprised of much later, George Russell ('A.E.'), Bertram Dobell, E.C. Stedman and his publishers (Houghton, Mifflin), and W.B. Yeats. Through these negotiations, Mosher ensured that a number of his books would have primary status. The Mosher edition of George Russell's Homeward Songs by the Way (HI3) includes twenty poems provided by 'A.E.' that are not in the Dublin edition, and Michael Field's Underneath the Bough (H66) contains a new preface and authorial revisions, giving both volumes first-edition status; his edition of Dowson's Poems (H2 I 3), antedating John Lane's London edition of 1905 by three years, ranks as the first collected edition.

Many of Mosher's individual editions command attention, but only a 
handful can here be singled out. Among these, special notice should be given to his three facsimiles, two of which are reproduced by photolithography. Rossetti's Hand and Soul (HIO9; Miscellaneous Series VIII, I899) is a quasi-facsimile imitative of Morris's Kelmscott edition, in which the type, resembling Golden, is surrounded by four variations of Morris's borders. Fitzgerald's Rubáiyát was one of Mosher's favourite books, and he reprinted it in no fewer than four series. The facsimile (H226, the last volume in the Reprints of Privately Printed Books Series, I902) is of the first edition of 1859 . It was printed in 250 copies, Io on Roman vellum, numbers I-5 of which contained an original etching by Edwin Edwards, a cancelled frontispiece to the third British edition. The book of which Mosher was proudest was his literal facsimile, down to the binding itself, of Whitman's I855 Leaves of Grass (H667, Miscellaneous LxxxvII, I9I9). Whitman was unquestionably Mosher's favourite American poet, and through Whitman's literary executor, Horace Traubel, he acquired most of Whitman's editions, including Leaves, and a manuscript for his personal library. Not a facsimile, but one of the most handsome of all Mosher's productions and representative of the kind of book that most appealed to him is The Garland of Rachel (H225, Reprints of Privately Printed Books XI, I902), originally issued in I $88 \mathrm{I}$ by the Daniel Press in 36 copies only - I 8 with variant title pages for the I 8 contributors, the remainder 'By Divers Kindly Hands' - and one of the scarcest of all nineteenth-century privately printed books. For his reprint, Mosher wrote a nineteen-page preface outlining his eventually successful search for a copy of the book, and supplied an Appendix containing both a history of the volume by Henry R. Plomer and a bibliography by Henry W. Poor, the famous collector. One of Mosher's most ambitious projects is his third printing of Wilde's poems in the Poetical Works of Oscar Wilde (H435, Miscellaneous Series XLI, I908; the other two have already been mentioned). A thick octavo in blue boards, the volume contains a bibliographical index and six facsimiles of title pages of Wilde's separately printed works. Mosher's black orchid, for me at least, is his reprint of the Pre-Raphaelite magazine, The Germ, the pure vellum edition of which is a magnificent specimen of book production. Mosher plundered many other serials - The Oxford and Cambridge Magazine, Undergraduate Papers, The Dark Blue - for materials, printing in the Bibelot all the fugitive writings by William Morris he could identify. The Germ, with admirable perspicacity, he printed in toto, replete with photographic reproductions of its covers and illustrations and embellished by the addition of James Ashcroft Noble's essay, 'A Pre-Raphaelite Magazine.'

Although not a trained scholar, Mosher was interested in textual variants (as opposed to bibliographical points), and he treats them in the prefaces to many of his editions. A number of his volumes, such as The Blessed 
Damozel (HI 8, Miscellaneous Series Xv, I90I), in which he sought, unsuccessfully, to improve on Rickett's Vale Press edition, contain collations that must have been enormously valuable at the time. Some volumes contain detailed bibliographies, such as that by Bertram Dobell and J.M. Wheeler in Mosher's second book, James Thomson's The City of Dreadful Night (H2, English Reprint Series II, I892). An amusing episode in Mosher's printing career was his accidental reprinting of two of Thomas J. Wise's fabrications in the Bibelot, Morris's Two Sides of the River and Swinburne's Dead Love (HI I 8 and I94; Reprints from the Bibelot Series vi and X, I899 and I90I). Dead Love was condemned on three counts of paper, type, and imprint in J.W. Carter and H.G. Pollard's An Enquiry into the Nature of Certain Nineteenth-Century Pamphlets (1934); Morris's pamphlet, only suspect in I934, was indicted as a forgery by Maurice Pariser in I950 and confirmed in Nicolas Barker and John Collins's recent Sequel to an Enquiry (Scolar 1983). Needless to say, neither reprint is mentioned by either $\mathrm{H}$. Buxton Forman or Wise in their respective bibliographies of Morris and Swinburne. And Wise was too grand to own books by Mosher, who is not represented in the Ashley Catalogue.

To these titles must be added Andrew Lang's Aucassin and Nicolete (HI2, the first volume in the Old World Series, I895), only because it sparked the first charge against Mosher for piracy, a fact he freely, and from the evidence of his letters, unashamedly admitted. In I896, Lang drew Mosher into an invidious correspondence that ran sporadically for nearly a year in the Critic. In a long letter of defence printed in the number for I I July I 896, Mosher presented legal, moral, and aesthetic justifications for his actions. Legally, he was, of course, perfectly within his right since no application had been made to copyright Lang's work, originally published in 1887 , in the United States by either the author or the publisher, David Nutt. Mosher was no more culpable than dozens of other American publishers, though he did offer to pay Lang a post facto honorarium, which Lang publicly disparaged. Mosher's moral and aesthetic grounds were less convincing, and his argument that he had 'faithfully printed an inaccessible book' led Lang to denounce him as a Robin Hood of publishing, a charge parodied in a ballad entitled 'The Publishing Privateer' in the Critic on ro October I896, which concluded:

Dear Andrew of the brindled mane,

The Yankee pirate may be rude;

But anger never yet has slain

This literary Robin Hood.

Mosher was neither slain, nor, even, chastened: he went on to publish four 
selections from Lang in the Bibelot and four further books in three series, and to use an essay by Lang as the preface to his I90 r edition of Edgar Allan Poe. And Lang's Aucassin and Nicolete went through nine Mosher editions! Mosher weathered two further exposures of his piratical practices: the first in the Publishers' Circular in 1909, when the editor, R.B. Marston, conducted a survey of Mosher's pirated authors for their opinions of his practices; the second in The Times in I9I4, in a series of letters initiated by James B. Blackwood, the President of the Publishers' Association of Great Britain and Ireland, whose particular grievance related to the importation of Mosher's books into Britain. But Mosher did not on either occasion enter the lists to defend himself. Surprisingly, one British publisher, Grant Richards, came to Mosher's defence, arguing that the term 'pirate' was inaccurately applied to Mosher and urging that the proper course to curtail Mosher's (and other publishers') legal activities, was for the British government to pressure the United States to 'enter into a more comprehensive agreement in matters of copyright.' Many of Lang's fellow writers objected to what The Times called 'The Mosher Method,' but others, like George Russell, William Sharp's alter ego, Fiona MacLeod, and Richard Le Gallienne were both pleased with Mosher's presentation of their works and happy for the American exposure. Even Bridges and Meredith wrote flattering letters to Mosher expressing their gratitude; and Le Gallienne wrote a lengthy tribute to Mosher, which the publisher printed no less than three times - in a catalogue, in the Index to the Bibelot, and separately (H734).

As Keith Huntress noted several years ago, Mosher was quite literally caught on the horns of an ethical dilemma: had he not pirated, he could not have been a publisher. That a number of his victims felt that the end justified the means does not, in absolute terms, exculpate Mosher, but it does offer an explanation, and perhaps even a justification, for his life's endeavours, aptly expressed in two quotations on which it is suitable to close. In I903, Le Gallienne inscribed a copy of his book, An Old Country House: 'To Thomas Bird Mosher: A Highwayman of Letters who robs us with such grace, that not to be robbed by him would be a disappointment: From a humble victim of his art.' Twenty years later, after Mosher's death, Christopher Morley made this metaphorical assessment of Mosher's practices:

If it be piracy to take home a ragged waif of literature found lonely by the highway, to clothe her in the best you have and find her rich and generous friends - if this be piracy, then let any other publisher who has never loitered a little in the Public Domain cast the first Stone and Kimball. (Amphora 2, p. II 31 
Thomas Bird Mosher - publisher of more than Iooo separate items, pirate, editor, anthologist, bibliographer, author lof 236 prefaces to the separate numbers of the Bibelot, of dozens of introductions to his published books, and of many essays and poems), who introduced Americans to 'the literature of rapture' through the writings of the Pre-Raphaelites, the French Symbolists, and the poets of the Celtic Revival - would doubtless have agreed, though he would have phrased it in a more mannered style, reminiscent of Pater. 